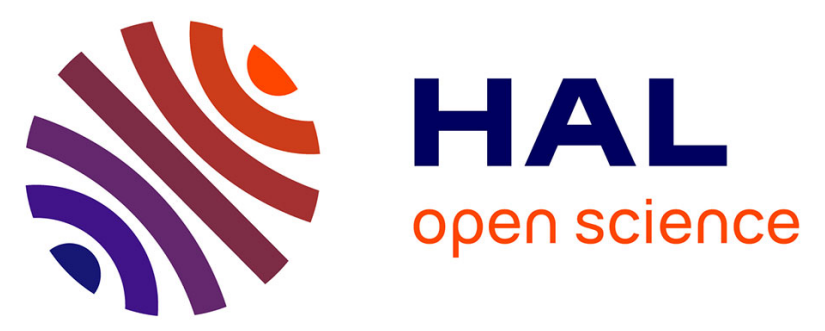

\title{
Geoinformation Approach in Soil Erosion Susceptibility Assessment - A Tool for Decision Making: Case Study of the North-Western Bulgaria
}

\author{
Valentina Nikolova, Emil Dimitrov, Plamena Zlateva
}

\section{To cite this version:}

Valentina Nikolova, Emil Dimitrov, Plamena Zlateva. Geoinformation Approach in Soil Erosion Susceptibility Assessment - A Tool for Decision Making: Case Study of the North-Western Bulgaria. 2nd International Conference on Information Technology in Disaster Risk Reduction (ITDRR), Oct 2017, Sofia, Bulgaria. pp.190-201, 10.1007/978-3-030-18293-9_16 . hal-02280329

HAL Id: hal-02280329

https://hal.inria.fr/hal-02280329

Submitted on 6 Sep 2019

HAL is a multi-disciplinary open access archive for the deposit and dissemination of scientific research documents, whether they are published or not. The documents may come from teaching and research institutions in France or abroad, or from public or private research centers.
L'archive ouverte pluridisciplinaire HAL, est destinée au dépôt et à la diffusion de documents scientifiques de niveau recherche, publiés ou non, émanant des établissements d'enseignement et de recherche français ou étrangers, des laboratoires publics ou privés. 


\title{
Geoinformation Approach in Soil Erosion Susceptibility Assessment - a Tool for Decision Making: Case Study of the North-Western Bulgaria
}

\author{
Valentina Nikolova ${ }^{1}$, Emil Dimitrov ${ }^{2}$ and Plamena Zlateva ${ }^{3}$ \\ ${ }^{1}$ Department of Geology and Geoinformatics, MGU, Sofia, Bulgaria \\ v.nikolova@mgu.bg \\ ${ }^{2}$ Institute of Soil Science, Agrotechnology and Plant Protection, Sofia, Bulgaria \\ e.dimitrov7@gmail.com \\ ${ }^{3}$ Institute of Robotics - BAS, Sofia, Bulgaria \\ plamzlatevalabv.bg
}

\begin{abstract}
The soil erosion is considered as one of the most serious environmental problem in a global scale. The development of the process could have negative impact on water, vegetation and ecosystem as a hole, as well as to influence on the quality of life. If the process is not mitigated in long term it could change the topographic surface and to trigger geomorphological hazards. The researches on soil erosion require analyses of large volume of information about soil properties, topographic surface, precipitation and land use. In the current research GIS technology is used for building the data base, spatial analyses and visualization of the results. The Universal Soil Loss Equation (USLE) is applied in Map Algebra and spatial distribution of soil loss is presented. The results are considered in relation to land use, particularly arable lands and vineyards. The application of computer technology provide opportunities for easy processing of data and updating the model by adding new data which can be used by territorial planning experts, local authorities and farmers in the planning process, monitoring and mitigating the soil erosion.
\end{abstract}

Keywords: Soil erosion, USLE, GIS, Land use, Geoinformation approach

\section{Introduction}

Soil erosion is a geomorphological process of loss of the soil layer due to the activity of rain and snowmelt water. It is characterised not only by the amount of soil lost, but also by reducing its fertility because of the removal of the superficial layer. The effects of soil erosion are not determined only by the reduction of agricultural productivity. Decreasing the soil quality reflects on the state of the vegetation as a whole and in this relation to the ecosystem conditions and ecosystem services. Soil erosion also affects the quality of water by increasing the rate of siltation which leads to limitation the initial storage capacity of the dam and this could be very dangerous because of the flood risk. 
In long term the soil erosion could contribute to the aggravation of the food problem and to influence the quality of life.

The average annual soil loss in natural conditions are between 0.0045 and $0.45 \mathrm{t} / \mathrm{ha}$, and increase from a 45 to $450 \mathrm{t} / \mathrm{ha}$ at arable land [1] depending on the soil properties and slope. Soil losses between 20 to $40 \mathrm{t} /$ ha caused by a rainfall in Europe may occur once every three years, and the erosion of extreme rainfalls reaches up to $100 \mathrm{t} / \mathrm{ha}$ once every 6 years. The researches show that water erosion takes $53 \%$ of total soil degradation [2]. Approximately $65 \%$ of the agricultural land in Bulgaria is at risk of water erosion and about $24 \%$ of wind erosion. A prerequisite for the development of water erosion processes is the prevailing hilly relief with slopes above 3 degrees. Average nearly 70 intensive rains fall on the territory of the country in the period April - October, and nearly $14 \%$ of them are erosive [3].

All these issues ground the need of studying the soil erosion and looking for tools to limit the processes. Taking into account the nature of the erosion process a large volume of data about precipitation, soil properties, topographic surface, vegetation and land use have to be processed and analysed. This determines wide application of information technology in erosion researches, which shows rapid development. There are many publications in which GIS is applied to the conventional methods of erosions assessment [4-9]. Most of the publications are based on the calculation of the USLE and some modifications are added regarding the characteristics of the area and the available data.

The aim of the current research is to build a GIS data base containing the soil erosion triggering factors and soil properties in the North-Western Bulgaria and to assess the erosion susceptibility of the region. This could support decision makers in agriculture and spatial planning. The soil loss is spatially presented in GIS by calculating the USLE on the base of raster layers about MFI, soil erodability, topography and vegetation cover. The results are compared with the land use in order to reveal how erosion is related to land use patterns.

\section{Study Area}

The area, subject of the current research is the north-western part Bulgaria (Fig. 1). Its limits are the Danube River at the north, the Bulgarian-Serbian border at the west, Stara Planina Mountain at the south and south-west and the river Iskar at the eastern side. It includes part of the Danube plain and Fore-Balkan. The total area is around $10217 \mathrm{~km} 2$. This is mainly an agricultural land. The relief is predominantly flat and hilly, and lowmountainous in the southern part of the study area. Regarding the soil zonation the study area is in the border of Northern Bulgaria Forest-Steppe zone [10]. It is divided into three subzones - Danube sub-zone of chernozems; Danube plain, hilly Fore-Balkans sub-zone of gray forest soils and Fore Balkan sub-zone of light gray forest soils. The hilly-plain terrain deeply cut by river valleys and continental climate in this aria define soil erosion as the main degradation threat for the topographic surface. 


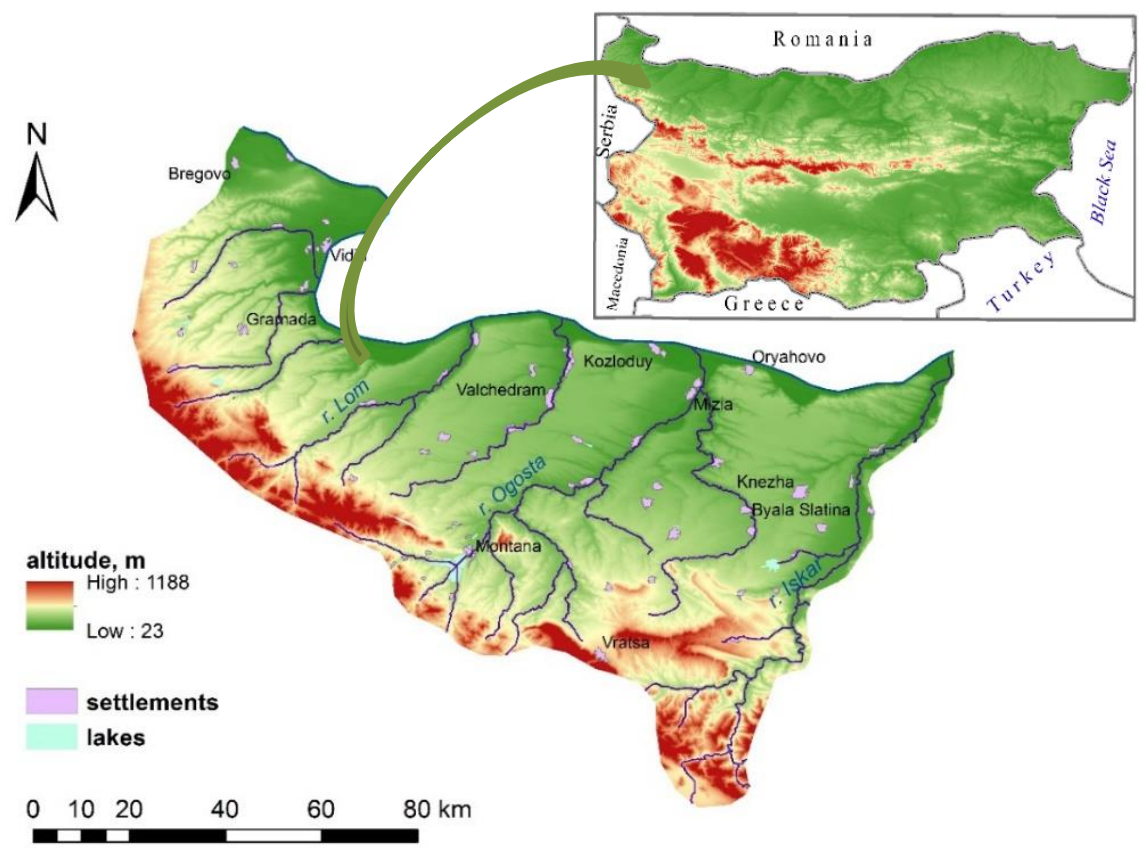

Fig. 1. Study area

\section{Data and Methodology}

Taking into account the identity of the modelled phenomena (soil erosion) a variety data is needed to be analyzed. This includes soils properties, rainfall intensity, slope of the topographic surface, vegetation cover and land use types.

The soil polygons are determined on the base of soil map of Bulgaria, M 1:400 000 and 12 soil units are outlined (Table 1). Soils profiles, representative for main soil types in Bulgaria are taken into consideration for determining the physical and chemical properties of the soils. The names of soils units are defined according to Bulgarian classification [11]. The soils are classified according to World Reference Base [12] and American classification [13]. The referencing of the soils in the studied region to the both classification systems cited here and the properties of the reference soil profiles [14] used as input data for GIS are given on Table 1.

The rainfall data used in the current research is taken from Meteorological bulletins (published by National Institute of Meteorology and Hydrology, Bulgaria) and form thematic climate data website: https://en.climate-data.org. Data from 8 meteorological stations in the study area is used in the research (Fig. 2). Other 8 stations, located in Romania and Serbia, near to the investigated area, are also used for spatial interpolation of the rain data. We did not consider for interpolation meteorological stations, located to the south of the study area because of the climate impact of the mountain ridge which borders the region and different climate conditions south of the Stara Planina Mountain. 
Table 1. Soil units in the investigated area referred to the WRB and Soil Taxonomy and input data for GIS: main soil texture fractions - sand $(2-0.050 \mathrm{~mm})$, silt $(0.050-0.002 \mathrm{~mm})$, clay $(<0.002 \mathrm{~mm})$; total organic Carbon (OC).

\begin{tabular}{|c|c|c|c|c|c|c|c|}
\hline No & $\begin{array}{l}\text { Bulgarian soil } \\
\text { classiffication }\end{array}$ & WRB (2006) & $\begin{array}{l}\text { Soil Taxonomy } \\
(2010)\end{array}$ & $\begin{array}{l}\text { Sand, } \\
\text { \%wt. }\end{array}$ & $\begin{array}{l}\text { Silt, } \\
\text { \%wt. }\end{array}$ & $\begin{array}{l}\text { Clay, } \\
\text { \%wt. }\end{array}$ & $\begin{array}{l}\text { OC, } \\
\text { \%wt. }\end{array}$ \\
\hline 1 & $\begin{array}{l}\text { Calcareous } \\
\text { chernozems/ } \\
\text { Typical } \\
\text { chernozems }\end{array}$ & $\begin{array}{l}\text { Epicalcic } \\
\text { Chernozem }\end{array}$ & $\begin{array}{l}\text { Calcic } \\
\text { Haploxerolls }\end{array}$ & 14.4 & 51.4 & 34.1 & 2.3 \\
\hline 2 & $\begin{array}{l}\text { Leached } \\
\text { chernozems }\end{array}$ & $\begin{array}{l}\text { Endocalcic } \\
\text { Chernozem }\end{array}$ & Typic Calciustolls & 14.6 & 46.9 & 38.6 & 2.6 \\
\hline 3 & $\begin{array}{l}\text { Leached } \\
\text { chernozem- } \\
\text { karasolutcii }\end{array}$ & $\begin{array}{l}\text { Endocalcic } \\
\text { Vertic } \\
\text { Chernozem }\end{array}$ & Vertic Haplustolls & 7.3 & 40.9 & 51.7 & 4.1 \\
\hline 4 & $\begin{array}{l}\text { Degraded } \\
\text { chernozems }\end{array}$ & $\begin{array}{l}\text { Luvic } \\
\text { Chernozem }\end{array}$ & Typic Agialbolls & 15.2 & 48.4 & 36.5 & 2.1 \\
\hline 5 & $\begin{array}{l}\text { Dark Gray- } \\
\text { Brown forest } \\
\text { soil }\end{array}$ & $\begin{array}{l}\text { Luvic Grayc } \\
\text { Phaeozem }\end{array}$ & Typic Argiudolls & 20.0 & 42.9 & 37.5 & 2.0 \\
\hline 6 & $\begin{array}{l}\text { Gray-Brown } \\
\text { forest soil }\end{array}$ & $\begin{array}{l}\text { Cutanic } \\
\text { Luvisols }\end{array}$ & Typic Hapludalfs & 31.3 & 34.4 & 34.9 & 2.0 \\
\hline 7 & $\begin{array}{l}\text { Light grey } \\
\text { forest soils }\end{array}$ & $\begin{array}{l}\text { Luvic } \\
\text { Endogleyic } \\
\text { Planosol }\end{array}$ & Typic Albaqualfs & 26.3 & 46.7 & 26.7 & 1.9 \\
\hline 8 & $\begin{array}{l}\text { Brown forest } \\
\text { soil }\end{array}$ & $\begin{array}{l}\text { Haplic } \\
\text { Cambisol }\end{array}$ & Typic Dystrudepts & 58.4 & 26.4 & 15.2 & 1.8 \\
\hline 9 & $\begin{array}{l}\text { Alluvial and } \\
\text { alluvial } \\
\text { meadow soils }\end{array}$ & $\begin{array}{l}\text { Haplic } \\
\text { Fluvisol }\end{array}$ & Typic Fluvents & 38.1 & 38.8 & 23.0 & 2.0 \\
\hline 10 & $\begin{array}{l}\text { Deluvial and } \\
\text { deluvial } \\
\text { meadow soil }\end{array}$ & $\begin{array}{l}\text { Haplic } \\
\text { Cambisol } \\
\text { (Colluvic) }\end{array}$ & Typic Orthents & 50.0 & 30.8 & 19.2 & 2.24 \\
\hline 11 & Eroded soils & Regosols & Entisols & 21.6 & 56.2 & 22.3 & 1.3 \\
\hline 12 & Rendzina soil & $\begin{array}{l}\text { Rendzic } \\
\text { Leptosol }\end{array}$ & $\begin{array}{l}\text { Typic } \\
\text { Haprendolls }\end{array}$ & 18.3 & 37.5 & 44.2 & 4.05 \\
\hline
\end{tabular}

The topographic data is derived from remote sensing (RS) data - SRTM DEM, http://srtm.csi.cgiar.org [15] RS data, Sentinel-2 images (ESA, Copernicus Sentinel Data, 2017), is also used for determining the vegetation conditions. Land cover/ land use data, taken from CORINE Land Cover Project [16], is used for evaluation of the relation between soil erosion susceptibility model and land use in order to suggest recommendations for more rational territorial planning. 
The methods used in the current research are grouped the following groups: mathematical; spatial analyses /spatial interpolation and GIS application. The last ones could be considered as an integrated approach for analyzing a spatial data.

For the aim of the research, the soil erosion susceptibility is determined on the base of Universal Soil Loss Equation, USLE [17] and revised USLE (RUSLE), [18]:

$$
A=R * K * L S * C * P,
$$

where: $A$ is the soil loss ( $\mathrm{t} / \mathrm{ha} / \mathrm{an})$;

$R$ - the rainfall erosion factor;

$K$ - the soil erodibility factor;

$L S$ - the topographical factor (slope-length and slope-steepness);

$C$ - the land cover and management factor;

$P$ - the factor of the works for erosion prevention and control

We applied the USLE in ArcGIS environment using Map Algebra tool on raster layers of the 5 indices involved in the model.

The rainfall erosion factor, $\mathrm{R}$ (rainfall intensity) is presented by modified Fournier index (MFI), proposed by Arnoldus [19]. It is calculated as the sum of monthly average amount of precipitation divided to the average annual amount of precipitation. The MFI is used in many publications for assessment the erosion and particularly when there is insufficient data for intensive rain, and also because of it can be easy calculated. The spatial distribution of the MFI is presented by inverse distance weighted (IDW) interpolation and a raster layer in ArcGIS is generated.

The soil erodibility ( $\mathrm{K}$ factor) is defined as the rate of soil loss. It represents the susceptibility of soil particles to be detached. It is related to the integrated effects of rainfall, runoff, and infiltration on soil loss [7]. The K values are calculated on the base of physical properties of the soil, the content of silt, clay, fine sand and organic matter. As a base for calculation, we used soil map in vector format presenting different soil types. In case of insufficient information on soil structure and texture, we used the grain size and the content of organic matter for calculating the $\mathrm{K}$ factor. The equation suggested by Römkens [20] and revised in Renard et al. [18] is the base of calculation. In order to take into account the organic matter content in calculating the $\mathrm{K}$ factor we used the following equation, proposed by Wang et al. [21]:

$K=0.0067-0.0013[\ln (S O M / D g)-5.6706]^{2}-0.015 \exp \left[28.9589(\log (D g)+1.827)^{2}\right]$,

where $S O M$ is soil organic matter, and

$$
D g=\exp \left(0.01 \sum_{i=1}^{n} f_{i} \operatorname{lnm}_{i}\right)
$$

$m_{i}$ is the arithmetic mean of the particle size,

$f_{i}$ is the weight percentage of the particle size fraction.

The soil erodibility values are calculated using the data in the soil polygon attribute table. The values are recorded in a new field in the attribute table. In the next step, the soil map is converted in raster format using $\mathrm{K}$ value field to be applicable in Map Algebra calculations. 
The topographic factor (LS - length of slope and steepness) is calculated using the flow accumulation and slopes values determined in ArcGIS environment on the base of DEM. Flow accumulation present the number of cells from which each cell in the raster collect flows. The following equation proposed by Moore and Burch [22, 23] is used.

$$
L S=\left(A^{*} \text { cell size } / 22.13\right)^{0.4}(\sin (\text { slope }) / 0.0896)^{1.3},
$$

where $A$ is flow accumulation.

Greater values of flow accumulation indicate more water quantity in the streams. LS factor presents the combined influence of the slope of the topographic surface and the length of slope. The steeper slopes determine more intensive erosion processes, while longer slopes could decrease the intensity of the erosion.

The land cover and management factor $(\mathrm{C})$ is determined on the base of Normalized Difference Vegetation Index (NDVI). It is an indicator for the state of vegetation and could be used in soil erosion estimation in relation to the impact of vegetation on the runoff distribution. Vegetation plays an important role in protecting soil against erosion because the vegetation canopy intercepts the rainfall, increases the infiltration and reduces the surface runoff erosion activity. The Sentinel 2 images (ESA, Copernicus Sentinel Data, 2017) are used for calculation of NDVI.

Satellite images used for determining the vegetation state are acquired in September when the crops are already collected from the field. In this regard, the values of erosion could be overestimated but following the precautionary principle, we decided to assess the soil erosion susceptibility taking into account the worse conditions.

The $C$ factor is determined using the following equation [24]:

$$
C=\exp (-2 * N D V I /(1-N D V I))
$$

No special actions for erosion prevention and control are taken in the investigated area and in this regard, 1 is accepted for $P$ factor.

\section{$4 \quad$ Results}

The parameters of USLE are calculated and presented as a separate GIS layers (Figures 2, 3, 4 and 5)

The location of the meteorological stations influence on the results of the interpolation but although some data imperfection the results show a regular increase of precipitation to the higher altitude (Fig. 2).

The values of soil erodability reflect the combined influence of mechanical composition of soils and the content of organic substance. The $\mathrm{K}$ factor has higher values at unconsolidated fluvisols and also at luvisols and planosols where silt and clay content is low. 


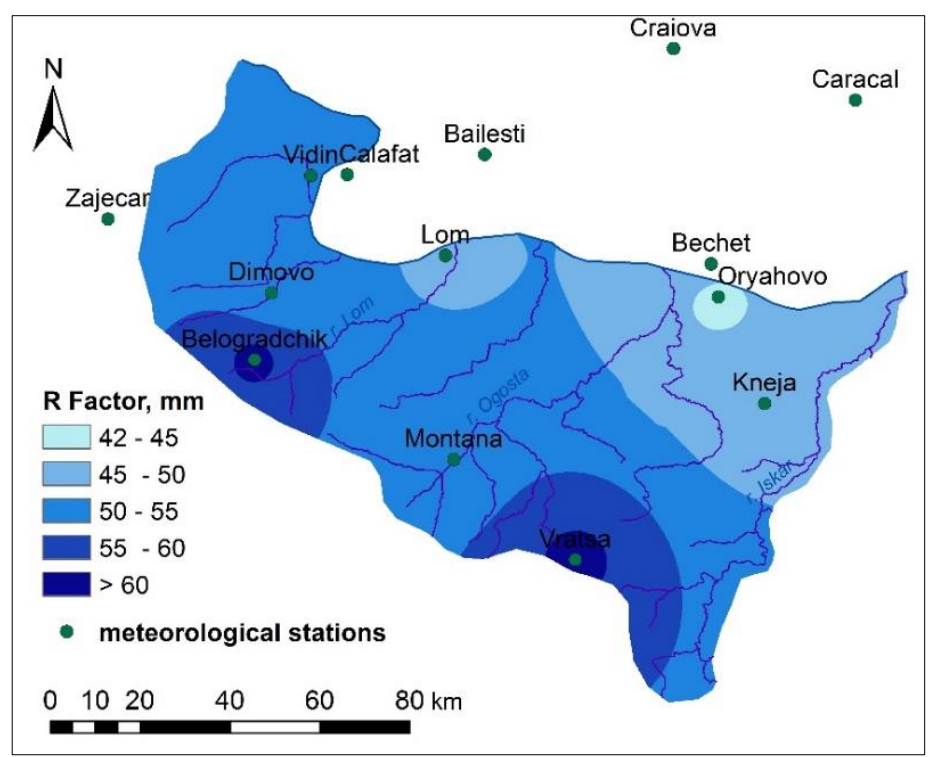

Fig. 2. Rainfall intensity

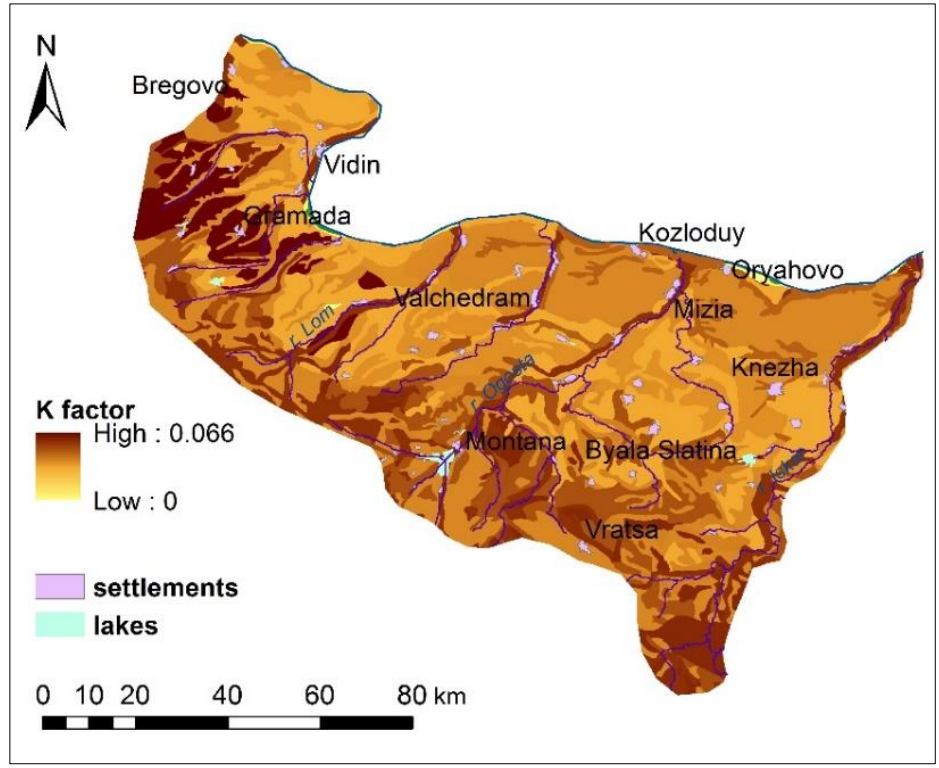

Fig. 3. Soil erodability (ha MJ mm) 


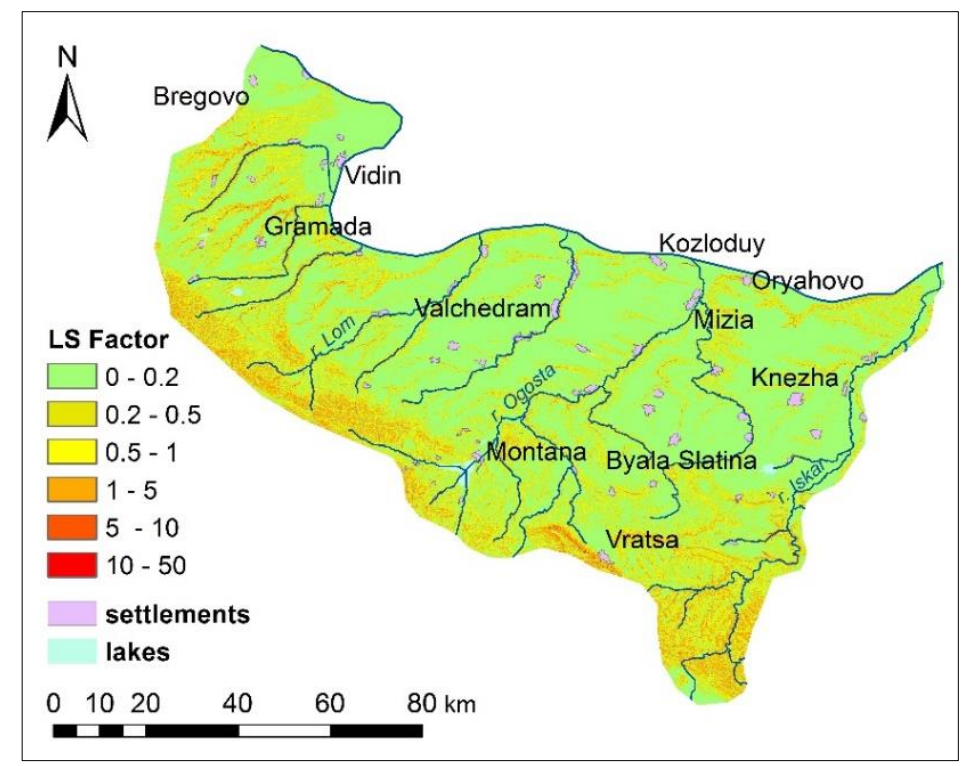

Fig. 4. Length of slope and steepness factor

Regarding the spatial distribution of LS factor the most of the investigated area $(68.9 \%$ ) has values less than 0.2 and $12.8 \%$ are between 0.2 and 0.5 . The highest class of LS factor $(10-50)$ takes only $0.1 \%$ of the investigated area and it could be skipped regarding the scale of the map.

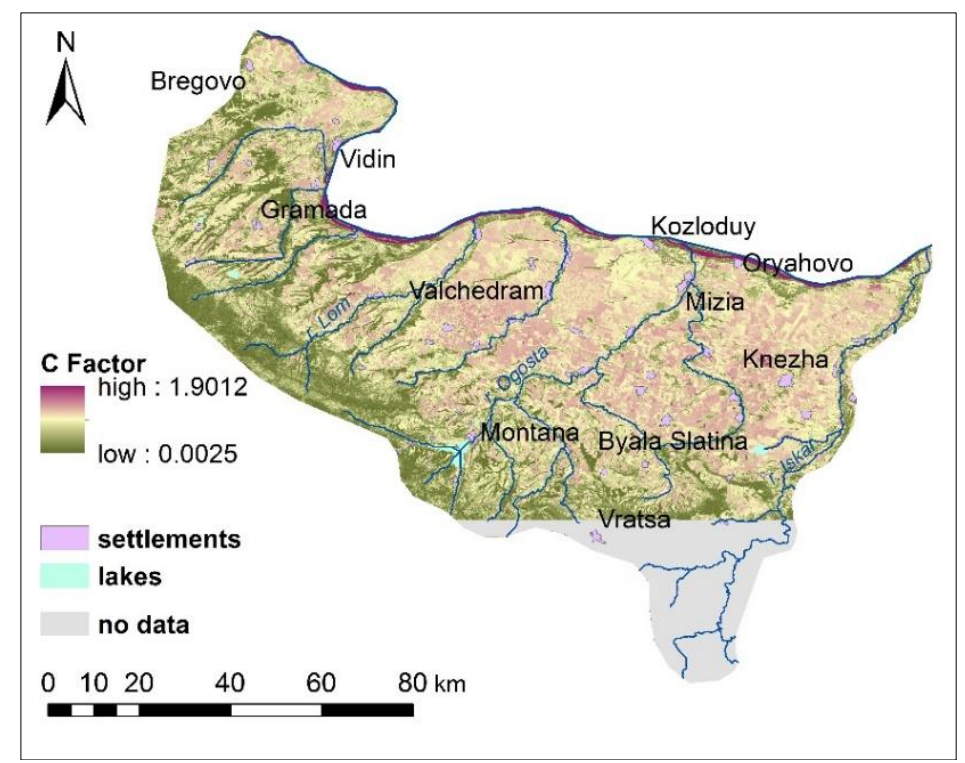

Fig. 5. The land cover factor 
The spatial distribution of $\mathrm{C}$ factor shows increasing of the values from the mountain and forest area to the hilly and low agricultural lands.

Multiplication of the above four raster layers in Map Algebra results in output raster presenting the soil loss (Fig. 6).

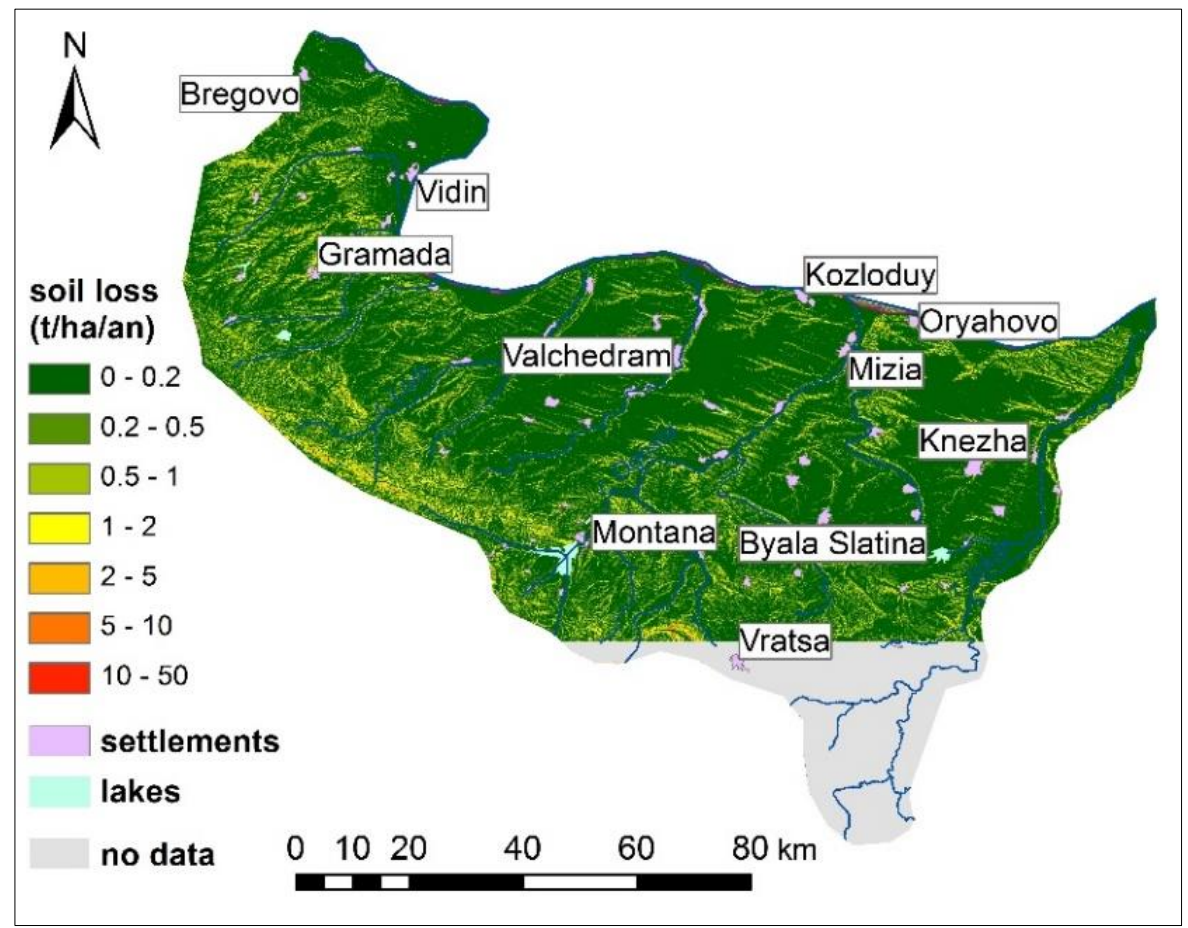

Fig. 6. Soil erosion

The generated model of soil erosion shows high values of soil loss in the high mountains at the southern part of the study area as well as to the north-west where hilly lands and rare vegetation are dominant. More than $1 \mathrm{t} / \mathrm{ha} / \mathrm{an}$ is the soil erosion near to rivers and streams which shows a clear relation of the presented USLE model to the river and gully erosion. The soil loss values are the lowest on the low and flat watersheds. The soil loss is less than $0.2 \mathrm{t} / \mathrm{ha} / \mathrm{an}$ in around $72 \%$ of the investigated area and in $0.06 \%$ of the area the calculated soil erosion is between 10 and $50 \mathrm{t} / \mathrm{ha} / \mathrm{an}$. The spatial overlay of the calculated soil erosion layer and land cover/land use (CORINE Land Cover Project) shows that $78.5 \%$ of the arable land and $62.7 \%$ of the vineyards have soil erosion less than $0.2 \mathrm{t} / \mathrm{ha} / \mathrm{an}$ (Table 2).

More attention should be given to the arable lands and vineyards where erosion is between 0.2 and $1 \mathrm{t} / \mathrm{ha} / \mathrm{an}$, which have relatively high percent of the respective land use types. The relevant agricultural activities (tillage across the slope, crop rotation etc.) should be carried out in these cases. 
Table 2. Soil erosion rates by land use

\begin{tabular}{ccc}
\hline $\begin{array}{c}\text { Soil loss, } \\
\text { t/ha/an }\end{array}$ & Arable lands, \% & Vineyards, \% \\
\hline $0-0.2$ & 78.4461 & 62.67932 \\
$0.2-0.5$ & 13.08564 & 21.9962 \\
$0.5-1$ & 6.070217 & 11.50664 \\
$1-2$ & 1.95048 & 3.233397 \\
$2-5$ & 0.396003 & 0.523719 \\
$5-10$ & 0.04343 & 0.045541 \\
$10-50$ & 0.008135 & 0.01518 \\
\hline
\end{tabular}

\section{Conclusion}

The application of USLE and generated model of soil erosion show that the investigated area is not severely affected by erosion processes. A special attention should be given to the hilly land and steep slopes of river valley and gullies. In case of deforestation there is a risk of increasing the erosion processes in the high parts of the mountain. The time of the year in which the vegetation / land cover data has been collected influences on the result of the research and should be taken into account in analysis the values of soil erosion. The vegetation data for current model is calculated using satellite data acquired in September (Sentinel-2) when the crops are collected. The result would be different if the assessment is done for May when vegetation is in a growing season. Having regard the above we did not use data of May because of the higher values of clouds cover and also the aim of the research was to assess the erosion rate in the worst conditions.

Although some uncertainties of the model, using of remote sensing data and computer technology allows acquisition of data for large areas (even difficultly accessible on the field), processing of a large amount of data and easily performing of spatial analyses. The integration of the soil erosion calculation model in geographic information systems (GIS) leads to an automatic cartographic representation and better interpretation of land erodibility data.

The results of the research could support the decision making related to the landscape planning, agricultural planning and soil preservation activities.

Future researches will be directed to the minimizing data imperfections, adding other factors influencing the erosion processes, for example water of melting snow, support practice factor etc. and improving the model.

\section{Acknowledgement}

The authors express their gratitude to the Bulgarian National Science Fund for the partial financial support under the Grant № DFNI - I02/15 from 12.12.2014, titled "Information System for Integrated Risk Assessment from Natural Disasters". 


\section{References}

1. Morgan, R. P. C.: Soil erosion and conservation. Longman group UK limited. (1995).

2. Oldeman, R., Hakkeling, T., Sombroekl W.: World map on the status of human-induced soil degradation. An explanatory note. Global assessment of soil degradation. GLASOD. ISRICWinand Centre-ISSS-FAO-ITC, Wageningen (1991).

3. Rousseva, S.: Validation of models for estimating soil erosion factors and rates. Journal of Balkan Ecology 5(1), 87-93 (2002),

4. Mitasova, H., Hofierka, J., Zlocha, M., Iverson, L. R.: Modelling topographic potential for erosion and deposition using GIS, International Journal of Geographical Information Systems 10 (5), 629-641 (1996).

5. Yuksel, A., Gundogan, R., Abdullah, E. A.: Using the Remote Sensing and GIS Technology for Erosion Risk Mapping of Kartalkaya Dam Watershed in Kahramanmaras, Turkey. Sensors 8, 4851-4865 (2008).

6. Liangjun, H., Haijun, Y., Qinke, Y., Rui, L.: A GIS-based Modeling Approach for Fast Assessment of Soil Erosion by Water at Regional Scale, Loess Plateau of China. Chinese Geographical Science 20(5), 423-433 (2010).

7. Lahlaoi, H.; Rhinane, H.; Hilali, A.; Lahssini, S.; Khalile, S.: Potential Erosion Risk Calculation Using Remote Sensing and GIS in Oued El Maleh Watershed, Morocco. Journal of Geographic Information System 7, 128-139 (2015).

8. Prasannakumar, V, Vijith, H., Abinod, S., Geetha N.: Estimation of soil erosion risk within a small mountainous sub-watershed in Kerala, India, using Revised Universal Soil Loss Equation (RUSLE) and geo-information technology. Geoscience Frontiers 3 (2), 209-215 (2012).

9. Sotiropoulou, A.-M., Alexandridis, T., Bilas, G., Karapetsas, N., Tzellou, A., Silleos, N., Misopolinos, N.: A user friendly GIS model for the estimation of erosion risk in agricultural land using the USLE. In M. Salampasis, A. Matopoulos (eds.): Proceedings of the International Conference on Information and Communication Technologies for Sustainable Agri-production and Environment (HAICTA2011), Skiathos, 8-11 September, 2011.

10. Koynov, V., Kabakchiev, I., Boneva, K.: Atlas of the soils in Bulgaria. Zemizdat Press, Sofia (in Bulgarian) (1998).

11. Yolevsky, M., Hadzhiyanakiev, A.: Agro-grouping of soils in Bulgaria, Extended systematic list, Code of groups and soil varieties. Institute of Soil Science Nikola Poushkarov, Sofia, 89 p. (in Bulgarian) (1976).

12. IUSS Working Group WRB.: World reference base for soil resources 2006. World Soil Resources Reports No. 103. Rome, FAO. 128 p. (2006).

13. Soil Survey Staff.: Keys to Soil Taxonomy, 11th ed. USDA-Natural Resources Conservation Service, Washington, DC, 338 p. (2010).

14. Shishkov, T., Kolev, N.: The soils of Bulgaria. World Soils Book Series. Series Editor: Alfred E. Hartemink. Springer, 208 p. (2014).

15. Reuter, H.I., Nelson, A.; Jarvis, A.: An evaluation of void filling interpolation methods for SRTM data, International Journal of Geographic Information Science 21(9), 983-1008 (2007).

16. CORINE Land Cover 2012 project, http://eea.government.bg/bg/projects/korine-14/index

17. Wischmeier, W., Smith, D.: Predicting rainfall erosion losses. A guide to conservation planning, US Department of Agriculture, Washington, D.C. (1978).

18. Renard, K.G., Foster, G.R., Weessies, G.A., McCool, D.K., Yoder, D.C. (eds): Predicting Soil Erosion by Water: A guide to to conservation planning with the Revised Universal Soil 
Loss Equation (RUSLE). U.S. Department of Agriculture, Agriculture Handbook 703 (1997).

19. Arnoldus, H. M. J.: An approximation of the rainfall factor in the Universal Soil Loss Equation. In: Assessment of Erosion (ed. by M. De Boodt \& D. Gabriels), Wiley, Chichester, UK, 127-132 (1980).

20. Römkens: The soil erodibility factor: a perspective. In: El-Swaify, S.A., W.C. Moldenhauer, A. Lo (eds.) Soil erosion and conservation. (1985).

21. Wang, B., Zheng, F., Guan, Y.: Improved USLE-K factor prediction: A case study on water erosion areas in China, International Soil and Water Conservation Research 4, 168-176

22. Moore, I., Burch, G.: Physical basis of the length-slope factor in the universal soil loss equation. Soil Science Society of America Journal 50, 1294-1298 (1986a).

23. Moore, I., Burch, G.: Modeling erosion and deposition: topographic effects. TRANS of ASAE 29 (6), 1624-1640 (1986b)

24. Van der Knijff, J. M., Jones, R. J. A, Montanarella, L.: Soil erosion risk assessment in Italy. European Soil Bureau. EUR 19044 EN (1999). 